\title{
Long-Term Adaptation of Acidophilic Archaeal Ammonia Oxidisers Following Different Soil Fertilisation Histories
}

\author{
Jun Zhao ${ }^{1,2} \cdot$ Baozhan Wang ${ }^{1,3} \cdot$ Xue Zhou $^{4} \cdot$ Mohammad Saiful Alam ${ }^{1,5} \cdot$ Jianbo Fan $^{1} \cdot$ Zhiying Guo $^{6}$. \\ Huimin Zhang ${ }^{1}$. Cécile Gubry-Rangin ${ }^{2}$ (i) . Jia Zhongjun ${ }^{1}$
}

Received: 6 October 2020 / Accepted: 21 April 2021 / Published online: 10 May 2021

(c) The Author(s) 2021

\begin{abstract}
Ammonia oxidising archaea (AOA) are ecologically important nitrifiers in acidic agricultural soils. Two AOA phylogenetic clades, belonging to order-level lineages of Nitrososphaerales (clade C11; also classified as NS-Gamma-2.3.2) and familylevel lineage of Candidatus Nitrosotaleaceae (clade C14; NT-Alpha-1.1.1), usually dominate AOA population in low pH soils. This study aimed to investigate the effect of different fertilisation histories on community composition and activity of acidophilic AOA in soils. High-throughput sequencing of ammonia monooxygenase gene (amoA) was performed on six low $\mathrm{pH}$ agricultural plots originating from the same soil but amended with different types of fertilisers for over 20 years and nitrification rates in those soils were measured. In these fertilised acidic soils, nitrification was likely dominated by Nitrososphaerales AOA and ammonia-oxidising bacteria, while $\mathrm{Ca}$. Nitrosotaleaceae AOA activity was non-significant. Within Nitrososphaerales AOA, community composition differed based on the fertilisation history, with Nitrososphaerales $\mathrm{C} 11$ only representing a low proportion of the community. This study revealed that long-term soil fertilisation selects for different acidophilic nitrifier communities, potentially through soil $\mathrm{pH}$ change or through direct effect of nitrogen, potassium and phosphorus. Comparative community composition among the differently fertilised soils also highlighted the existence of AOA phylotypes with different levels of stability to environmental changes, contributing to the understanding of high AOA diversity maintenance in terrestrial ecosystems.
\end{abstract}

Keywords Soil nitrification $\cdot$ Nitrososphaerales $\cdot$ Ca. Nitrosotaleaceae $\cdot$ AmoA $\cdot$ Low pH $\cdot$ Fertilisation

\section{Introduction}

Acidic soils consist of almost $30 \%$ of the world's land area and half of arable fields [1]. In the past decade, soil acidity has been intensified due to increasing amount of ammoniumbased fertilisers applied in agricultural lands in China and

Jun Zhao and Baozhan Wang contributed equally to this work.

Cécile Gubry-Rangin

c.rangin@abdn.ac.uk

$\triangle$ Jia Zhongjun

jia@issas.ac.cn

1 State Key Laboratory of Soil and Sustainable Agriculture, Institute of Soil Science, Chinese Academy of Sciences, Nanjing 210008, China

2 School of Biological Sciences, University of Aberdeen, Cruickshank Building, St. Machar Drive, Aberdeen AB24 3UU, UK globally [2]. Although reduced soil $\mathrm{pH}$ impairs many belowground biochemical processes [3], nitrification appears not to be affected as similar rates occurred in acidic and neutral soils [4]. Nevertheless, there is evidence for $\mathrm{pH}$ niche specialisation of ammonia oxidisers [5, 6]. The initial and rate limiting step of nitrification, the conversion of ammonia to nitrite, is performed by ammonia oxidising archaea (AOA), canonical bacteria (AOB) and more recently discovered

3 Key Lab of Microbiology for Agricultural Environment, Ministry of Agriculture, College of Life Sciences, Nanjing Agricultural University, Nanjing 210095, China

4 College of Agricultural Science and Engineering, Hohai University, Nanjing 210098, China

5 Department of Soil Science, Bangabandhu Sheikh Mujibur Rahman Agricultural University, Gazipur 1706, Bangladesh

6 Soil Subcenter of Chinese Ecological Research Network, Institute of Soil Science, Chinese Academy of Sciences, Nanjing 210008, China 
complete ammonia bacterial oxidisers (commamox). While knowledge on comammox distribution and activity in soils is still scarce, AOA rather than AOB activity was shown to control ammonia oxidation in most of the low $\mathrm{pH}$ soils [7-10]. In contrast, both AOA and AOB appeared active in neutral to alkaline soils $[11,12]$, despite some recent evidence of AOB activity in acidic soils [13, 14]. It was further demonstrated that soil $\mathrm{pH}$ might determine the niche specialisation of diverse phylogenetic clades, both for AOA [5] and AOB [15]. AOA are phylogenetically placed into clades from three orders, including Nitrososphaerales, Nitrosopumilales and Candidatus Nitrosocaldales [16]. Several AOA taxonomic rankings based on the key functional gene, ammonia monooxygenase amoA, have been proposed in the literature and the one focusing on terrestrial AOA [5] was chosen in the present study (with correspondence with a global AOA classification [17] being presented in Fig. 1). Among the phylogenetically well characterised 19 AOA clades (cluster 1-19, C1-C19), two clades are particularly abundant in acidic and acido-neutral soils (C11 within the order-level lineage of Nitrososphaerales and C14 within the family-level lineage of $\mathrm{Ca}$. Nitrosotaleaceae), while others, less abundant, also appear well-adapted to such environments (e.g. Nitrososphaerales C6 or some members of Nitrososphaerales C13) [18]. Many ecological studies have confirmed high abundance or activity of Nitrososphaerales and/or $C a$. Nitrosotaleaceae AOA in acidic soils $[9,19,20]$, but the environmental factors regulating their distribution are still not elucidated.

Ammonium-based $\mathrm{N}$ fertilisers might stimulate different groups of ammonia oxidisers, due to potential distinct affinities to and/or competitivity for substrate [21-23]. Therefore, this study aimed to test the hypothesis that different fertilisation sources also influence the AOA nitrifier community distribution in low $\mathrm{pH}$ agricultural soils. Indeed, it was previously observed that long-term $\mathrm{N}$ fertilisation affected $\mathrm{AOA}$ rather than $\mathrm{AOB}$ community compositions in low pH fields [24]. Specifically, while $\mathrm{Ca}$. Nitrosotaleaceae AOA were observed with no amendment of nitrogen $(\mathrm{N})$, phosphorus $(\mathrm{P})$ or potassium $(\mathrm{K})$ elements, soils amended

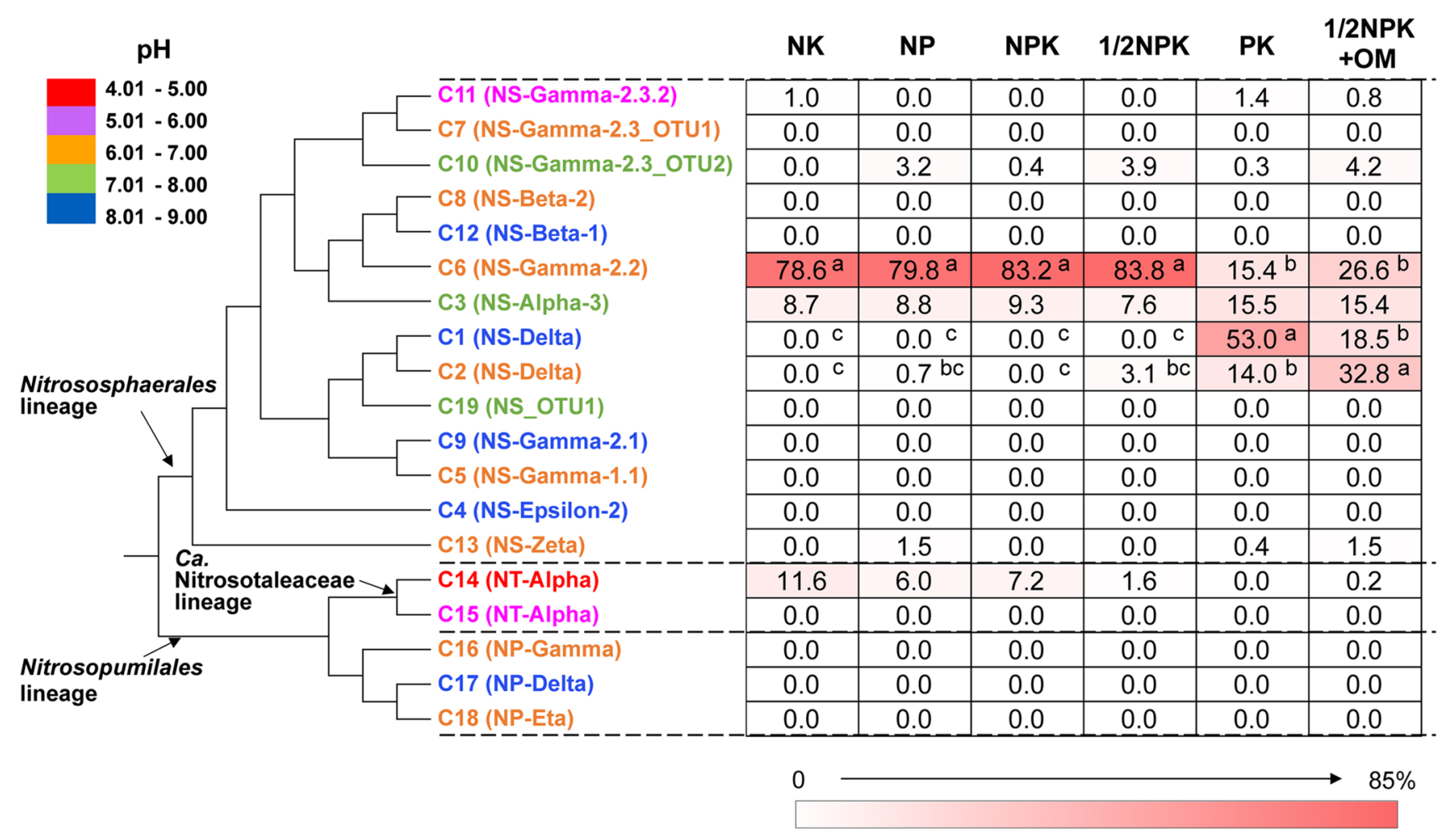

Fig. 1 Heatmap displaying the relative abundance of different phylogenetic clades of ammonia oxidising archaea within the class Nitrososphaeria, estimated by pyrosequencing of archaeal amoA gene fragments. The phylogeny of different clades was constructed using known representative amoA gene sequences from each clade. Names of the phylogenetic clades include initial terrestrial denomination (C1-C19) [18] and more recent denomination of these clades is indicated in brackets [17] to unify the two phylogenetic approaches. The colour of a phylogenetic clade name indicates the $\mathrm{pH}$ specialisation of the clade from previous meta-analysis at a global scale [18]. Soils were ranked from low to high $\mathrm{pH}$ conditions (from left to right). Different letters $(\mathrm{a}-\mathrm{c})$ next to the relative abundance values for clades $\mathrm{C} 1, \mathrm{C} 2$ and C6 indicate significant difference in relative abundance between soils with different fertilisation history $(p \leq 0.05)$ 
with all those three elements (NPK) contained exclusively Nitrososphaerales-affiliated AOA [24]. This suggests that nutrient element limitation might be an important niche differential factor for acid-tolerant or acidophilic AOA groups, with the implication that Nitrososphaerales AOA are more competitive than $\mathrm{Ca}$. Nitrosotaleaceae AOA under multiple nutrient enriched condition (i.e. fertilised with NPK or organic manure compost). To test this hypothesis, we characterised the AOA community in several low $\mathrm{pH}$ agricultural soils being subject to different fertilisation managements for $>20$ years using high-throughput sequencing of the archaeal ammonia monooxygenase $(a m o A)$ gene. We predict that (i) AOA community is dominated by $\mathrm{Ca}$. Nitrosotaleaceae and Nitrososphaerales AOA and more specifically by acidophilic clades of $\mathrm{C} 14$ and $\mathrm{C} 11$, and (ii) the relative abundance of Nitrososphaerales AOA will increase with multiple nutrient supplies (with NPK or manure amendment). In addition, this study aimed to identify the environmental variables potentially affecting the community composition and provide evidence for the distinct relative contribution of different ammonia oxidiser groups (Nitrososphaerales, Ca. Nitrosotaleaceae AOA and AOB) to nitrification in acidic agricultural soils under different fertilisation regimes.

\section{Materials and Methods}

\section{Site Description and Soil Sampling}

The long-term fertilisation experiment fields are located at the Ecology Experimental Station of Red Soil, Chinese Academy of Sciences $\left(28^{\circ} 15^{\prime} \mathrm{N}, 116^{\circ} 55^{\prime} \mathrm{E}\right)$ in the city of Yingtan, province Jiangxi of China. This region has a typical subtropical monsoon climate with a mean annual precipitation of $1785 \mathrm{~mm}$ and a mean annual temperature of $18{ }^{\circ} \mathrm{C}$. Soil derives from quaternary red clay and is classified as Hapludults. The fertilisation experiment was initially established in 1989 with a peanut-rutabaga rotation system, and since 1995 was maintained as cropping of peanut with fallow in winter. Soil samples were collected from different fields receiving different fertilisation regimes with descriptions as follows: (1) PK, plots without $\mathrm{N}$ fertilisation but amended with $\mathrm{P}$ and $\mathrm{K}$; (2) NP, plots receiving chemical $\mathrm{N}$ fertiliser and amended with $\mathrm{P}$; (3) NK, plots receiving chemical N fertiliser and amended with K; (4) NPK, plots receiving chemical $\mathrm{N}$ fertilisers and amended with $\mathrm{P}$ and $\mathrm{K}$; (5) $1 / 2 \mathrm{NPK}$, plots receiving same types of fertilisers as in NPK plots but with half amount; and (6) $1 / 2 \mathrm{NPK}+\mathrm{OM}$, plots receiving the same fertilisers as in $1 / 2 \mathrm{NPK}$ plots plus additional organic manure. The annual application rates of $\mathrm{N}, \mathrm{P}$ and $\mathrm{K}$ were $120 \mathrm{~kg}$ urea-N/hm ${ }^{2}, 40 \mathrm{~kg} \mathrm{P}_{2} \mathrm{O}_{5}-\mathrm{P} / \mathrm{hm}^{2}$ and $118 \mathrm{~kg} \mathrm{~K}{ }_{2} \mathrm{O}-\mathrm{K} / \mathrm{hm}^{2}$, respectively, and the $1 / 2 \mathrm{NPK}+\mathrm{OM}$ received additional $15,000 \mathrm{~kg} / \mathrm{hm}^{2}$ swine manure in addition to $1 / 2 \mathrm{NPK}$ fertilisation. Each treatment was applied to three field plots and soil was collected in each plot as one biological replicate. For each biological replicate, soil samples at $0-20 \mathrm{~cm}$ depth were collected during fallow period within each plot from five random cores (with distance of 2-3 m between cores) in May 2012, sieved through a 2.0-mm sieve and homogenized to make a composite sample. The subsamples were kept at $4{ }^{\circ} \mathrm{C}$ until analysis for soil physiochemical analysis, and at $-20^{\circ} \mathrm{C}$ for genomic DNA extraction.

\section{Soil Physiochemical Analysis}

Soil $\mathrm{pH}$ was determined using a soil-to-water ratio of 1:5 with a Mettler Toledo 320-S pH meter (Mettler-Toledo Instruments Co. Ltd., Shanghai, China). Soil organic matter and total $\mathrm{N}$ were determined by dichromate oxidation method and Kjeldahl digestion method, respectively. Soil $\mathrm{NH}_{4}{ }^{+}$and $\mathrm{NO}_{3}{ }^{-}$concentrations were determined using a Skalar SAN Plus Segmented Flow Analyser (Skalar Inc., Breda, Netherlands) after extraction with $2 \mathrm{M} \mathrm{KCl}$ solution. Soil available $\mathrm{P}$ was extracted by sodium bicarbonate and analysed using the molybdenum blue method. Soil available $\mathrm{K}$ was extracted by ammonium acetate and estimated by flame photometry.

\section{Nucleic Acid Extraction and Pyrosequencing}

Soil DNA was extracted using a FastDNA spin kit for soil (MP Biomedicals, Cleveland, OH, USA), according to the manufacturer's instruction. The DNA quantity and purity were determined by a Nanodrop ND-1000 UV-Vis Spectrophotometer (NanoDrop Technologies, Wilmington, DE,

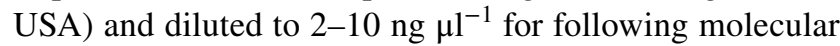
tests.

High-throughput sequencing of the amoA gene was performed using the primers CrenamoA 23f/CrenamoA 616r [25] with the forward primer containing unique barcode sequences for demultiplexing samples. PCR reaction was performed in a $50 \mu \mathrm{l}$ mixture containing $25 \mu \mathrm{l}$ of Platinum PCR SuperMix (Invitrogen, Shanghai, China), $1 \mu \mathrm{M}$ of each primer and $2 \mu$ of DNA template. The thermal condition was as follows: $94{ }^{\circ} \mathrm{C}$ for $3 \mathrm{~min}, 35$ cycles of $94{ }^{\circ} \mathrm{C}$ for $45 \mathrm{~s}$, $55{ }^{\circ} \mathrm{C}$ for $30 \mathrm{~s}$ and $72{ }^{\circ} \mathrm{C}$ for $90 \mathrm{~s}$, followed by extension at $72{ }^{\circ} \mathrm{C}$ for $5 \mathrm{~min}$. Negative control using sterile water instead of soil DNA was always included. PCR products were gelpurified and quantified using Picogreen dsDNA Quantitation Kits (Invitrogen). Adapter sequence was added to the forward end of the PCR amplicon fragments before performing the sequencing on a Roche FLX 454 pyrosequencing machine (Roche Diagnostics Corporation, Branford, CT).

The bioinformatic analyses of amplicon sequencing of marker genes included following key steps. Forward 
sequence reads were truncated at $350 \mathrm{bp}$ and reads were demultiplexed and quality filtered using Mothur [26]. Reads with average quality score $<25$, mismatched primers, ambiguous bases and frameshift errors were removed as described in a previously study [15]. The resultant sequences were assigned to a database of phylogenetic amoA gene clades (C1-C19) [5] using a BLASTn approach (www.ncbi.nlm. nih.gov).

\section{Quantification of Ammonia Oxidisers}

Real-time quantitative PCR (qPCR) was performed to determine archaeal and bacterial amoA gene abundances on a CFX96 Optical Real-Time Detection System (Bio-Rad, Laboratories Inc., CA, USA). Primer pair Arch-amoAF/ Arch-amoAR [27] was used and qPCR reaction was performed in a $25 \mu \mathrm{l}$ volume containing $12.5 \mu \mathrm{l}$ SYBR Premix Ex Taq (TaKaRa Biotechnology, Shiga, Japan), $1 \mu \mathrm{M}$ of each primer and $2 \mu \mathrm{l}$ of tenfold diluted DNA template (1-10 ng). Amplification conditions were as follows: $95^{\circ} \mathrm{C}$ for $1 \mathrm{~min}, 40$ cycles of $10 \mathrm{~s}$ at $95{ }^{\circ} \mathrm{C}, 30 \mathrm{~s}$ at $55^{\circ} \mathrm{C}, 1 \mathrm{~min}$ at $72{ }^{\circ} \mathrm{C}$, followed by plate reads at $83{ }^{\circ} \mathrm{C}$. Bacterial amoA gene was quantified using the primers amoA1F/amoA2R [28], with the same PCR conditions used for archaeal amoA gene quantification. The standards were generated and used as previously described [8]. qPCR was performed in biological triplicate each containing 3 technical replicates. Amplification efficiency was $98-103 \%$ with $R^{2}$ values $>0.99$. The specificity of real-time PCR amplification was confirmed by melting curve analysis and agarose gel electrophoresis at the end of each qPCR run.

\section{Nitrification Activity by ${ }^{15} \mathrm{~N}$-Isotope Tracing Microcosms}

${ }^{15} \mathrm{~N}$-isotope tracing was exploited to estimate nitrification activity under near-in situ incubation conditions. The incubation was established in triplicate in $250 \mathrm{ml}$ Erlenmeyer flask containing $10 \mathrm{~g}$ of the sieved fresh soil from each plot. The ${ }^{15} \mathrm{~N}$ labelled urea $\left({ }^{15} \mathrm{~N}\right.$ atom $\left.>98 \%\right)$ was applied to the soil at a final concentration of $5 \mu \mathrm{g} \mathrm{N} \mathrm{g}^{-1}$ dry soil, which approximated to the $\mathrm{NH}_{4}{ }^{+}-\mathrm{N}$ concentration in soils under in situ condition. The soil was incubated at $25{ }^{\circ} \mathrm{C}$ in darkness for 7 days in the absence or presence of $0.1 \%(\mathrm{v} / \mathrm{v})$ acetylene, an inhibition gas for ammonia oxidation. The production of soil ${ }^{15} \mathrm{~N}$-labelled nitrate and nitrite $\left(\mathrm{NO}_{\mathrm{x}}{ }^{-}\right)$after 7 -day incubation was measured and calculated as previously described $[8,29]$.

\section{Statistical Analysis}

The putative relative ammonia oxidiser contribution to ${ }^{15} \mathrm{NO}_{\mathrm{x}}{ }^{-}$production was estimated according to the ammonia oxidiser abundance and their recorded cell-specific activity. Firstly, the relative abundance of Nitrososphaerales and $\mathrm{Ca}$. Nitrosotaleaceae AOA was calculated based on highthroughput sequencing of $a m o A$ genes. The cell abundance of Nitrososphaerales and $\mathrm{Ca}$. Nitrosotaleaceae AOA was then calculated by multiplying the relative abundance by the total AOA abundance estimated by qPCR of $a m o A$ genes. The cell abundance of AOB was calculated as the bacterial amoA gene abundance divided by 2.5 , considering that one AOB cell contains on average 2.5 copies of amoA genes [30]. The putative proportions of Nitrososphaerales AOA, $\mathrm{Ca}$. Nitrosotaleaceae AOA and AOB in the ${ }^{15} \mathrm{NO}_{\mathrm{x}}{ }^{-}$production were then estimated according to previous record of specific cell activity of $2.6 \mathrm{fmol} \mathrm{NH}_{3}$ cell $^{-1} \mathrm{~h}^{-1}$ for Nitrososphaera viennensis [31], $0.072 \mathrm{fmol} \mathrm{NH}_{3}$ cell $^{-1} \mathrm{~h}^{-1}$ for $C a$. Nitrosotalea devanaterra [32], and $23 \mathrm{fmol} \mathrm{NH}_{3}$ cell $^{-1} \mathrm{~h}^{-1}$ for Nitrosospira multiformis [33], respectively. The specific cell activity records used here are from pure cultures under optimal cultivation conditions, and the relative contribution to the nitrification was estimated assuming they all reached these records in the soils as previously described [13].

Statistical analysis was performed on Statistics 23.0 (SPSS, IL, USA). One-way ANOVA was employed to determine the effect of different fertilisation treatments on soil ${ }^{15} \mathrm{NO}_{\mathrm{x}}{ }^{-}$production rate and relative abundance of each AOA clade (C1-C19), followed by a Tukey post hoc test to determine significant mean differences. Alpha diversity indices, including number of OTUs and Shannon's index, were calculated after random sampling of 400 reads per sample following OTU clustering at 100\% sequence identity. Non-metric multidimensional scaling (NMDS) based on a Bray-Curtis dissimilarity matrix was performed on AOA composition using the vegan package under $R$ environment, and analysis of similarity (ANOSIM) was used to assess the variations between soil sites [34]. Function 'envfit' was used to test the significance of chemical properties (as vectors) and fertilisation treatments (as factors) for the NMDS ordinations, with 999 permutations using vegan [34]. Differences at $p<0.05$ were considered statistically significant.

\section{Results}

\section{Changes in Soil Properties}

Soil $\mathrm{pH}$ was affected by different fertilisation regimes. The $\mathrm{pH}$ was lower in most soils receiving chemical $\mathrm{N}$ fertilisers ( $\mathrm{pH}$ 4.2-5.2; NK, NP, NPK and 1/2NPK) compared to the soil with no $\mathrm{N}$ fertilisation history ( $\mathrm{pH} \mathrm{5.7;} \mathrm{PK),}$ to the exception of the soil amended with additional supply of organic manure which had the highest $\mathrm{pH}(\mathrm{pH} 6.3$; $1 / 2 \mathrm{NPK}+\mathrm{OM}$ ) (Table 1). The soil with manure fertilisation also had the highest contents of soil organic matter (SOM), 
Table 1 Physiochemical properties of soils with different fertilisation history. Different letters (a-e) in each column indicate significant difference of a property between soils. $O M$, organic matter; $T N$, total $\mathrm{N} ; A P$, available $\mathrm{P} ; A K$, available $\mathrm{K}$

\begin{tabular}{llllllll}
\hline Treatments & $\mathrm{pH}$ & $\begin{array}{l}\mathrm{OM} \\
\left(\mathrm{g} \mathrm{kg}^{-1}\right)\end{array}$ & $\begin{array}{l}\mathrm{TN} \\
\left(\mathrm{g} \mathrm{kg}^{-1}\right)\end{array}$ & $\begin{array}{l}\mathrm{NH}_{4}^{+}-\mathrm{N} \\
\left(\mathrm{mg} \mathrm{kg}^{-1}\right)\end{array}$ & $\begin{array}{l}\mathrm{NO}_{\mathrm{x}}^{-}-\mathrm{N} \\
\left(\mathrm{mg} \mathrm{kg}^{-1}\right)\end{array}$ & $\begin{array}{l}\mathrm{AP} \\
\left(\mathrm{mg} \mathrm{kg}^{-1}\right)\end{array}$ & $\begin{array}{l}\mathrm{AK} \\
\left(\mathrm{mg} \mathrm{kg}^{-1}\right)\end{array}$ \\
\hline $\mathrm{NK}$ & $4.2^{\mathrm{d}}$ & $12.4^{\mathrm{b}}$ & $0.52^{\mathrm{c}}$ & $4.8^{\mathrm{c}}$ & $7^{\mathrm{c}}$ & $4^{\mathrm{e}}$ & $155^{\mathrm{d}}$ \\
$\mathrm{NP}$ & $4.8^{\mathrm{c}}$ & $10.7^{\mathrm{b}}$ & $0.67^{\mathrm{b}}$ & $5.3^{\mathrm{b}}$ & $10^{\mathrm{b}}$ & $46^{\mathrm{b}}$ & $69^{\mathrm{e}}$ \\
$\mathrm{NPK}$ & $4.9^{\mathrm{c}}$ & $10.7^{\mathrm{b}}$ & $0.75^{\mathrm{b}}$ & $5.0^{\mathrm{b}}$ & $12^{\mathrm{b}}$ & $36^{\mathrm{c}}$ & $249^{\mathrm{b}}$ \\
$1 / 2 \mathrm{NPK}$ & $5.2^{\mathrm{c}}$ & $10.6^{\mathrm{b}}$ & $0.66^{\mathrm{b}}$ & $5.3^{\mathrm{b}}$ & $11^{\mathrm{b}}$ & $26^{\mathrm{d}}$ & $172^{\mathrm{c}}$ \\
$\mathrm{PK}$ & $5.7^{\mathrm{b}}$ & $12.2^{\mathrm{b}}$ & $0.66^{\mathrm{b}}$ & $5.4^{\mathrm{b}}$ & $11^{\mathrm{b}}$ & $26^{\mathrm{d}}$ & $335^{\mathrm{a}}$ \\
$\begin{array}{l}1 / 2 \mathrm{NPK} \\
+\mathrm{OM}\end{array}$ & $6.3^{\mathrm{a}}$ & $16.4^{\mathrm{a}}$ & $1.03^{\mathrm{a}}$ & $6.7^{\mathrm{a}}$ & $20^{\mathrm{a}}$ & $319^{\mathrm{a}}$ & $173^{\mathrm{c}}$ \\
\hline
\end{tabular}

total $\mathrm{N}$, inorganic $\mathrm{N}$ (both $\mathrm{NH}_{4}{ }^{+}$and $\mathrm{NO}_{\mathrm{x}}{ }^{-}$) and available $\mathrm{P}$, whereas soil treatment $\mathrm{NK}$ had the lowest total $\mathrm{N}$, inorganic $\mathrm{N}$ and available $\mathrm{P}$ concentration (Table 1). Additionally, available $\mathrm{K}$ contents were the highest and the lowest in PK and NP treatments, respectively (Table 1).

\section{Compositional Change of Ammonia Oxidising Archaea}

Pyrosequencing of archaeal amoA gene fragments generated 81,958 raw sequences from all sites, with an average of 5061 raw reads (range between 2092 and 10,011 sequences) per sample. Two replicates from PK and 1/2NPK soils resulted in only 942 and 43 sequences, respectively, and were therefore removed from further analysis. Quality filtering of the sequences resulted in a total of 16,590 high-quality sequences from all sites, accounting for $20.2 \%$ of all original sequences. All AOA amoA sequences affiliated to the Nitrososphaerales and Ca. Nitrosotaleaceae lineages (Fig. 1 and Fig. S1), with Nitrososphaerales accounting for 88.4-100\% of amoA gene sequences in different soils. Nitrososphaerales $\mathrm{C} 6, \mathrm{C} 1, \mathrm{C} 2$ and $\mathrm{C} 3$ clades were the most abundant phylogenetic clades accounting for up to $83.8 \%, 53.0 \%, 32.8 \%$ and $15.5 \%$ of the AOA population, respectively (Fig. 1). In contrast, $\mathrm{Ca}$. Nitrosotaleaceae $\mathrm{C} 14$ accounted for up to $11.6 \%$ of the AOA population (Fig. 1). Within Nitrososphaerales, the relative abundance of the $\mathrm{C} 1, \mathrm{C} 2$ and $\mathrm{C} 6$ clades depended on the soil fertilisation histories, with $\mathrm{C} 1$ and $\mathrm{C} 2$ having the highest relative abundance in soils with no $\mathrm{N}$ fertilisation $(\mathrm{PK})$ or extra organic manure fertilisation $(1 / 2 \mathrm{NPK}+\mathrm{OM})$, which were the soils with the highest $\mathrm{pH}$ (Table 1), while C6 relative abundance was highest in the other soils (Fig. 1). Due to the shifts in the relative abundance of different AOA clades, AOA compositions were dissimilar in soils with different fertilisation histories, based on NMDS analysis (Fig. 2). Different fertilisation treatments had a significant effect on the AOA community compositions between higher ( $\mathrm{PK}$ and 1/2NPK + OM, pH 5.7-6.3) and lower (NK, NP, NPK and 1/2NPK, pH 4.2-5.2) pH soil groups $(p=0.002)$ following ANOSIM analysis based on

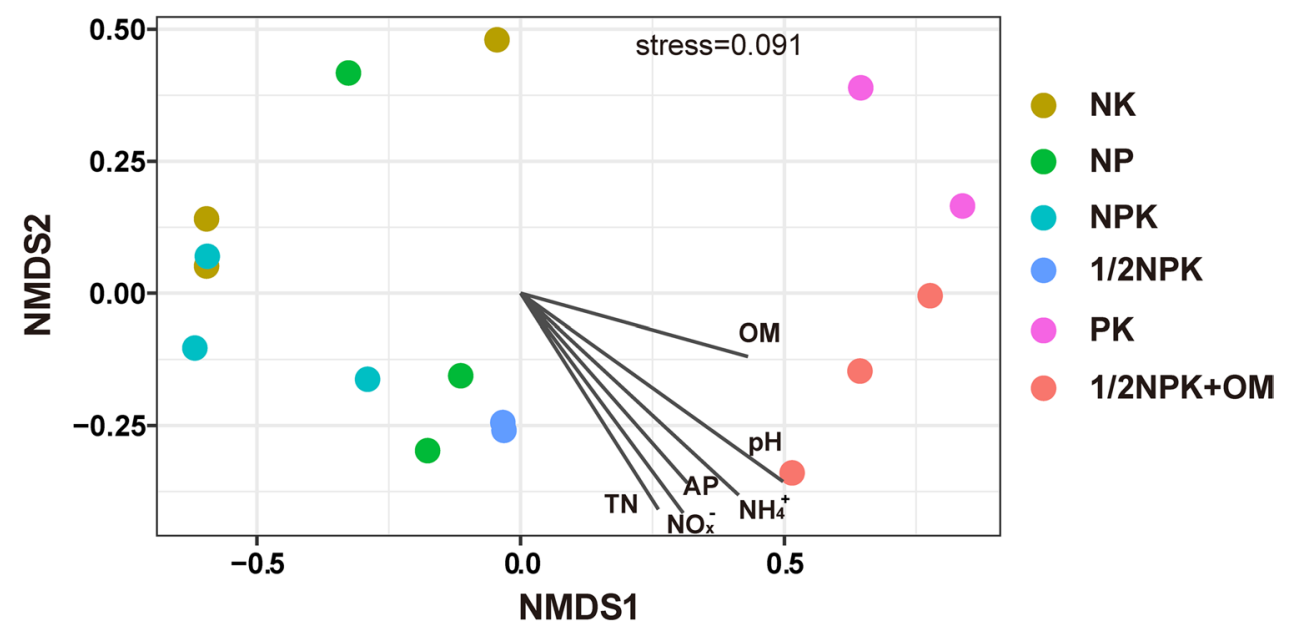

Fig. 2 Nonmetric multidimensional scaling plot of archaeal ammonia oxidiser community compositions in different soils based on normalized abundance of different AOA clades. The soils were ranked from low to high $\mathrm{pH}$ conditions (from top to bottom) in the figure legend. The association of measured environmental variables was shown as the grey line segments in the plot using 'envfit' function, with the length of the lines proportional to the correlations between environmental variables and the ordination values and the direction pointing to increasing values of the environmental variables 
the Bray-Curtis dissimilarity. Multivariate analyses showed that change in soil $\mathrm{pH}$ most strongly correlated with variation in AOA compositions among all tested environmental variables (Fig. 2 and Table S1). The alpha diversity indices of AOA, including richness (number of OTUs) and evenness (Shannon's index), were higher in PK and $1 / 2 \mathrm{NPK}+\mathrm{OM}$ soils than the other soils, although the difference was not significant for the richness index (Fig. S2).

\section{Ammonia Oxidiser Abundance}

Both AOA and AOB were detected in all soils by quantification of amoA genes. AOA gene abundance ranged between $4.9 \times 10^{7}$ and $1.3 \times 10^{8}$ per $g$ of soil, with the highest abundance being estimated in the soils with higher $\mathrm{pH}$ (Fig. 3a). After multiplying the total AOA gene abundance by the relative abundance of Nitrososphaerales and $C a$.
Nitrosotaleaceae (based on the pyrosequencing analysis), the abundance of these two clades was estimated to be $4.4 \times 10^{7}-1.3 \times 10^{8}$ and $0-6.6 \times 10^{6}$ per $g$ of soil, respectively (Fig. 3a). AOB gene abundance was significantly lower than AOA abundance in all soils, ranging from $1.4 \times 10^{6}$ to $3.7 \times 10^{7}$ per $g$ of soil (Fig. 3a).

\section{Nitrification Activity and Putative AO Contributions to Soil Nitrification}

Soil nitrification activity was assessed by temporal increase in ${ }^{15} \mathrm{~N}_{-} \mathrm{NO}_{\mathrm{x}}{ }^{-}$content converted from ${ }^{15} \mathrm{~N}-\mathrm{NH}_{4}{ }^{+}$amended in the microcosms after 7-day incubation. The highest nitrification activity was observed in the soil receiving organic manure $(1 / 2 \mathrm{NPK}+\mathrm{OM}$ treatment), while the lowest activity was detected in NK and NP soils (Fig. 3b). Acetylene fully inhibited nitrate production in all soil microcosms (Fig. S3).
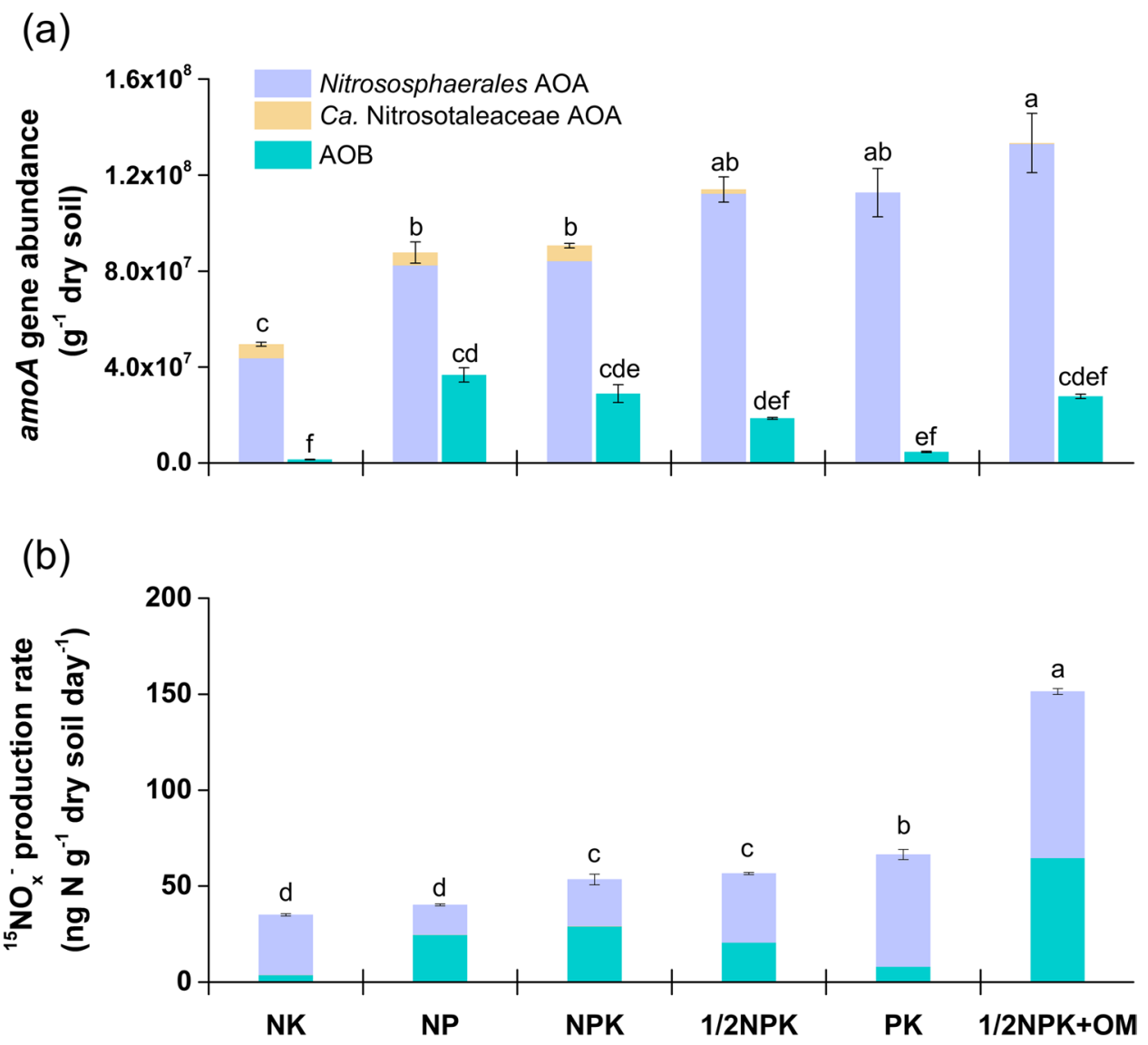

Fig. 3 Abundance (a) and putative contribution (b) of Nitrososphaerales AOA, Ca. Nitrosotaleaceae AOA and betaproteobacterial $\mathrm{AOB}$ to nitrification. a Total $\mathrm{AOA}$ and $\mathrm{AOB}$ abundances were estimated by qPCR of amoA genes, and Nitrososphaerales AOA and $\mathrm{Ca}$. Nitrosotaleaceae AOA abundances were calculated by multiplying total AOA abundance by the relative abundance of each AOA lineage. b Nitrification activity was estimated as the production rate of ${ }^{15} \mathrm{NO}_{\mathrm{x}}{ }^{-} \mathrm{N}$ converted from ${ }^{15} \mathrm{~N}$-urea following 7-day microcosm incubation and the putative contributions were estimated using specific cell activity of 2.6, 0.072 and $23 \mathrm{fmol} \mathrm{NH}_{3}$ cell $^{-1} \mathrm{~h}^{-1}$ for Nitrososphaerales AOA, Ca. Nitrosotaleaceae AOA and AOB, respectively. Soils were ranked from low to high $\mathrm{pH}$ conditions (from left to right). Error bars represent standard errors of means from triplicate microcosms and different letters above the bars indicate statistically significant differences $(p \leq 0.05)$ within each plot 
Putative ammonia oxidiser contributions to the nitrification rate were then estimated according to the ammonia oxidiser abundance and the recorded AOA and AOB cell-specific activity. Nitrososphaerales AOA and AOB were putatively the major contributors to nitrification in these soils, accounting for $38.9-89.5 \%$ and $10.1-60.9 \%$ of the nitrification rates, respectively, while $\mathrm{Ca}$. Nitrosotaleaceae AOA contribution was negligible ( $0-0.4 \%$ of the rates) (Fig. 3b).

Soil ${ }^{15} \mathrm{NO}_{\mathrm{x}}{ }^{-}$production rate was positively correlated with archaeal amoA gene abundance (polynomial best-fitting model: $\left.y=3 \mathrm{e}^{-14} x^{2}-4 \mathrm{e}^{-06} x+173, p=0.042\right)$ (Fig. 4b) but not with bacterial amoA gene abundance $(p=0.343)$ (Fig. 4b). Soil ${ }^{15} \mathrm{NO}_{\mathrm{x}}{ }^{-}$production rate also positively correlated with soil $\mathrm{pH}$ (polynomial best-fitting model: $y=34 x^{2}$ $-304 x+723, p=0.014$ ) (Fig. 4c). Additionally, soil pH positively correlated with AOA abundance but not AOB abundance (Fig. S4).

\section{Discussion}

\section{The Ecology of Nitrososphaerales and Ca. Nitrosotaleaceae AOA in Acidic Agricultural Soils}

This study predicted that Nitrososphaerales and $\mathrm{Ca}$. Nitrosotaleaceae clades dominate AOA population in the low $\mathrm{pH}$ agricultural soils, especially the clades of $\mathrm{C} 11$ and $\mathrm{C} 14$, which are the most abundant AOA clades in acidic soils based on a global database study [5, 35]. Unexpectedly, neither $\mathrm{C} 11$ nor $\mathrm{C} 14$ was retrieved as the main AOA nitrifiers in our soils, indicating that strong physiological adaptation to low soil $\mathrm{pH}$ was not restricted to these previously recognized AOA clades. Nonetheless, the relative abundance of $\mathrm{C} 14$ seemed to increase in the soils with a decreased $\mathrm{pH}$ (especially in NK soil, pH 4.2, Fig. 1), despite no statistical difference observed between different soils due to large replication variations in this study. This suggested great adaptability of
C14 to strongly acidic environment $(\mathrm{pH}<4.5)$, being consistent with previous studies showing strong AO activity of this clade in such soils (see list of SIP experiments in Table 2). Additionally, previous studies on acidic red soils from the same region (Yingtan, see Table 2) estimated that Nitrososphaerales $\mathrm{C} 11$ were the most abundant AOA in some forest soils while they were not detected in reclaimed agricultural soils, suggesting that this AOA clade might not be favoured under agricultural management. This might explain the generally low proportion of Nitrososphaerales C11 in all agricultural soils used in this study.

Instead of Nitrososphaerales $\mathrm{C} 11$ and $\mathrm{Ca}$. Nitrosotaleaceae $\mathrm{C} 14$, AOA population was dominated by Nitrososphaerales $\mathrm{C} 3, \mathrm{C} 6$ or $\mathrm{C} 1 / \mathrm{C} 2$ clades in our soils. However, these AOA clades had different levels of adaptability to different fertilisation histories, supposedly leading to distinct AOA compositions in these soils (Fig. 2). Nitrososphaerales clade $\mathrm{C} 3$ were detected at similar proportions in different soils, irrespective of different fertilisation history (Fig. 1 and Fig. S1), suggesting nitrifiers within this clade adapt to a wide range of environmental conditions and form the common and widespread archaeal nitrifiers in these soils. This consistently detected AOA clade might be considered 'habitat generalist' with similar distribution pattern in these soils [36], which can play a key role in maintenance of taxonomic diversity [37] and may have strong potential for dormancy [38]. In comparison, C6 and C1/2 showed higher sensitivity to environmental changes, as $\mathrm{C} 6$ were most abundant in lower $\mathrm{pH}$ soils (NK, NP, NPK and 1/2NPK, $\mathrm{pH}$ 4.2-5.2) and $\mathrm{C} 1 / 2$ dominated in more neutral $\mathrm{pH}$ soils (PK and $1 / 2 \mathrm{NPK}+\mathrm{OM}$, pH 5.7-6.3) (Fig. 1 and Fig. S1). The compensation of $\mathrm{C} 1 / \mathrm{C} 2$ abundance by $\mathrm{C} 6$ in lower $\mathrm{pH}$ soils suggests redundant function of distinct AOA phylotypes in soils, which might facilitate fast recovery of nitrification rate following environmental changes [39]. Similar trend was observed from a list of literatures (Table 2), as $\mathrm{C} 1 / \mathrm{C} 2$ clades only dominated $\mathrm{AOA}$ population in soils with $\mathrm{pH} \geq 5.7$ and (a)

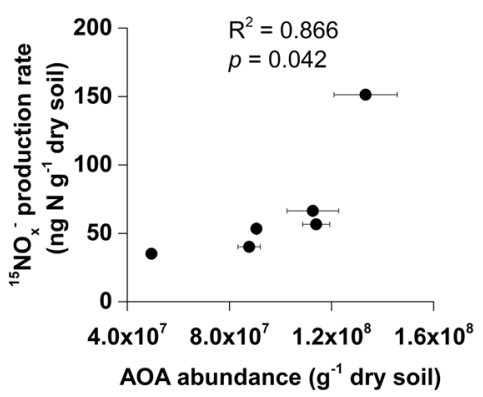

(b)

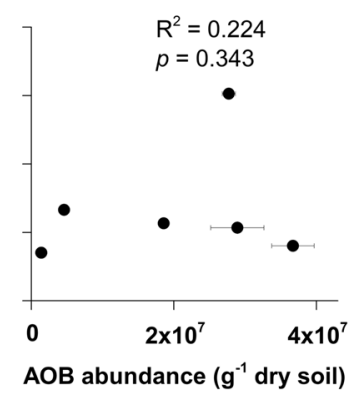

(c)

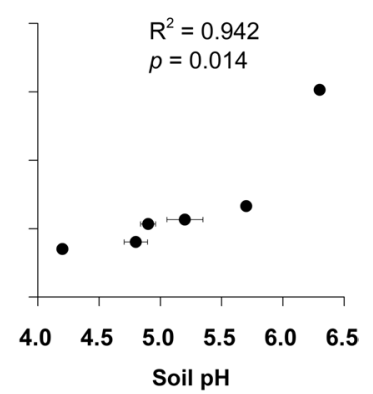

Fig. 4 Correlations of ${ }^{15} \mathrm{~N}^{-\mathrm{NO}_{3}}{ }^{-}$production rate with AOA abundance (a), AOB abundance (b) and soil $\mathrm{pH}(\mathbf{c})$. AOA and $\mathrm{AOB}$ abundances were estimated by qPCR of archaeal and bacterial amoA genes, respectively. Error bars represent standard errors of means from triplicate microcosms and regression coefficients of the best fitting model and associated $p$ values are indicated. Small standard error values were hidden by the mean value symbols 
Table 2 Non-restrictive meta-analysis of archaeal amoA gene communities in 35 acidic soils across China from 15 different studies. Studies were selected following the key topic word search 'amoA archaea acidic soil' in Web of Science. After manual curation, only studies on acidic agricultural soils with amoA sequencing data were included in the list for comparison with the present study. The archaeal amoA gene sequences were retrieved from GenBank and classified into 19 phylogenetic clades [5] by BLASTn approach. The table indicates the relative abundance of the main clades for each study when such estimation was possible. The full literature list is shown in supplementary Table S2

\begin{tabular}{|c|c|c|c|c|c|c|}
\hline Soil site & Source & $\mathrm{pH}$ & Main clade(s) & Analysis tool & Presence or active & literature \\
\hline \multicolumn{7}{|c|}{ Studies on different fertilisation histories } \\
\hline \multirow[t]{8}{*}{$\begin{array}{r}\text { 1. Qiyang } \\
\text { (Hunan) }\end{array}$} & Agricultural soil $(\mathrm{N})$ & 3.7 & $\begin{array}{l}\text { C14/C15 (55\%), C6 } \\
\quad(45 \%)\end{array}$ & Clone library & Presence & He et al. 2007 \\
\hline & $\begin{array}{l}\text { Agricultural soil } \\
\text { (NK) }\end{array}$ & 3.8 & $\begin{array}{c}\mathrm{C} 14 / \mathrm{C} 15(82 \%), \mathrm{C} 3 / \\
\mathrm{C} 6 / \mathrm{C} 11(18 \%)\end{array}$ & & & \\
\hline & $\begin{array}{l}\text { Agricultural soil } \\
\text { (NP) }\end{array}$ & 4.0 & $\begin{array}{l}\mathrm{C} 14 / \mathrm{C} 15(77 \%), \mathrm{C} 2 / \\
\mathrm{C} 6(23 \%)\end{array}$ & & & \\
\hline & $\begin{array}{l}\text { Agricultural soil } \\
\text { (NPK) }\end{array}$ & 4.0 & C6 (100\%) & & & \\
\hline & $\begin{array}{l}\text { Agricultural soil } \\
\text { (PK) }\end{array}$ & 5.0 & $\begin{array}{l}\mathrm{C} 14 / \mathrm{C} 15(12.5 \%) \\
\mathrm{C} 1 / \mathrm{C} 3 / \mathrm{C} 6 / \mathrm{C} 10 / \mathrm{C} 11 \\
\quad(87.5 \%)\end{array}$ & & & \\
\hline & $\begin{array}{l}\text { Agricultural soil (no } \\
\text { fertiliser) }\end{array}$ & 5.5 & $\begin{array}{l}\mathrm{C} 1 / \mathrm{C} 3 / \mathrm{C} 6 / \mathrm{C} 10 \\
(100 \%)\end{array}$ & & & \\
\hline & $\begin{array}{l}\text { Agricultural soil } \\
(\mathrm{NPK}+\mathrm{OM})\end{array}$ & 5.8 & C1/C6/C10 (100\%) & & & \\
\hline & $\begin{array}{l}\text { Agricultural soil } \\
\text { (Fallow) }\end{array}$ & 5.8 & C1/C3 (100\%) & & & \\
\hline \multirow{5}{*}{$\begin{array}{l}\text { 2. Nanchang } \\
\text { (Jiangxi) }\end{array}$} & Agricultural soil (N) & 5.3 & C6 & DGGE/Clone library & Presence & Shen et al. 2015 \\
\hline & $\begin{array}{l}\text { Agricultural soil } \\
\text { (CK) }\end{array}$ & 5.4 & $\mathrm{C} 6 / \mathrm{C} 10$ & & & \\
\hline & $\begin{array}{l}\text { Agricultural soil } \\
\text { (NPK) }\end{array}$ & 5.8 & C6/C10 & & & \\
\hline & $\begin{array}{l}\text { Agricultural soil } \\
\text { (OM) }\end{array}$ & 5.8 & $\mathrm{C} 1 / \mathrm{C} 2$ & & & \\
\hline & $\begin{array}{l}\text { Agricultural soil } \\
(\mathrm{NPK}+\mathrm{OM})\end{array}$ & 5.9 & $\mathrm{C} 1 / \mathrm{C} 2$ & & & \\
\hline \multicolumn{7}{|l|}{ Studies on Yingtan soil } \\
\hline \multirow{3}{*}{$\begin{array}{l}\text { 3. Yingtan } \\
\text { (Jiangxi) }\end{array}$} & Broad-leaf forest & 4.3 & C11 & DGGE/Clone library & Presence & Huang et al. 2011 \\
\hline & Bush forest & 4.4 & $\mathrm{C} 11 / \mathrm{C} 14$ & & & \\
\hline & Peanut soil & 4.8 & $\mathrm{C} 3 / \mathrm{C} 6$ & & & \\
\hline $\begin{array}{l}\text { 4. Yingtan } \\
\text { (Jiangxi) }\end{array}$ & Broad-leaf forest & 4.4 & C11 & Meta-genome & Presence & Wang et al. 2019 \\
\hline $\begin{array}{r}\text { 5. Yingtan } \\
\text { (Jiangxi) }\end{array}$ & Agricultural soil & 5.0 & C3/C13 & $\begin{array}{l}\text { T-RFLP/Clone } \\
\text { library }\end{array}$ & Presence & Wu and Conrad 2014 \\
\hline $\begin{array}{r}\text { 6. Yingtan } \\
\text { (Jiangxi) }\end{array}$ & Agricultural soil & 4.9 & C3 (100\%) & $\begin{array}{l}\text { DNA-SIP/Clone } \\
\text { library }\end{array}$ & Active & Wang et al. 2014a \\
\hline \multicolumn{7}{|l|}{ Other studies } \\
\hline $\begin{array}{l}\text { 7. Hangzhou } \\
\text { (Zhejiang) }\end{array}$ & Tea orchard & 3.8 & C14/C15 & $\begin{array}{l}\text { DNA-SIP/Clone } \\
\text { library }\end{array}$ & Active & Lu and Jia 2013 \\
\hline $\begin{array}{l}\text { 8. Hangzhou } \\
\text { (Zhejiang) }\end{array}$ & Tea orchard & 3.8 & $\mathrm{C} 14$ & $\begin{array}{l}\text { DNA-SIP/Clone } \\
\text { library }\end{array}$ & Active & Wang et al. 2019 \\
\hline $\begin{array}{l}\text { 9. Taoyuan } \\
\text { (Hunan) }\end{array}$ & Corn/seed rape & 4.0 & $\mathrm{C} 14$ & DGGE/Clone library & Presence & Shen et al. 2013 \\
\hline $\begin{array}{l}\text { 10. Hangzhou } \\
\text { (Zhejiang) }\end{array}$ & Tea orchard & 4.2 & C11/C15 & $\begin{array}{l}\text { DNA-SIP/Clone } \\
\text { library }\end{array}$ & Active & Zhang et al. 2012 \\
\hline \multirow[t]{2}{*}{$\begin{array}{l}\text { 11. Ningbo (Zhe- } \\
\text { jiang) }\end{array}$} & $\begin{array}{l}\text { Vegetable soil } \\
\text { (Native pH) }\end{array}$ & 4.0 & C3 $(97.5 \%)$ & $\begin{array}{l}\text { DNA-SIP/Clone } \\
\text { library }\end{array}$ & Active & Li et al. 2019 \\
\hline & $\begin{array}{l}\text { Vegetable soil (modi- } \\
\text { fied } \mathrm{pH} \text { ) }\end{array}$ & 4.8 & $\begin{array}{l}\text { C3 }(38 \%), \text { C1 }(35 \%), \\
\text { C2 }(17 \%)\end{array}$ & & & \\
\hline
\end{tabular}


Table 2 (continued)

\begin{tabular}{|c|c|c|c|c|c|c|}
\hline Soil site & Source & $\mathrm{pH}$ & Main clade(s) & Analysis tool & Presence or active & literature \\
\hline \multirow[t]{2}{*}{ 12. Hefei (Anhui) } & Vegetable soil & $4.3-6.3$ & $\mathrm{C} 14$ & 454-pyrosequencing & Presence & Song et al. 2016 \\
\hline & Vegetable soil & 7.0 & $\mathrm{C} 3$ & & & \\
\hline $\begin{array}{r}\text { 13. Jiansanjiang } \\
\text { (Heilongjiang) }\end{array}$ & Soybean field & 4.5 & $\mathrm{C} 11$ & Clone library & Presence & Wang et al. 2014b \\
\hline \multirow[t]{2}{*}{ 14. Ji'an (Jiangxi) } & $\begin{array}{l}\text { Citrus field (fertilisa- } \\
\text { tion) }\end{array}$ & $4.7-5.1$ & $\mathrm{C} 3 / \mathrm{C} 14$ & TFRLP/Clone library & Presence & Liu et al. 2017 \\
\hline & $\begin{array}{l}\text { Citrus field (no ferti- } \\
\text { lisation) }\end{array}$ & $5.0-5.1$ & $\mathrm{C} 14$ & & & \\
\hline \multirow[t]{4}{*}{$\begin{array}{l}\text { 15. Shenyang } \\
\text { (Liaoning) }\end{array}$} & $\begin{array}{l}\text { Agricultural soil } \\
\text { (high N fertilisa- } \\
\text { tion) }\end{array}$ & 5.2 & $\mathrm{C} 1 / \mathrm{C} 14$ & DGGE/Clone library & Presence & Xu et al. 2012 \\
\hline & $\begin{array}{l}\text { Agricultural soil } \\
\text { (medium N fertili- } \\
\text { sation) }\end{array}$ & 5.5 & $\mathrm{C} 1 / \mathrm{C} 3$ & & & \\
\hline & $\begin{array}{l}\text { Agricultural soil (low } \\
\mathrm{N} \text { fertilisation) }\end{array}$ & 5.6 & $\mathrm{C} 1 / \mathrm{C} 2 / \mathrm{C} 3$ & & & \\
\hline & $\begin{array}{l}\text { Agricultural soil (no } \\
\text { fertiliser) }\end{array}$ & 5.7 & $\mathrm{C} 1 / \mathrm{C} 2$ & & & \\
\hline
\end{tabular}

the C6 were often predominant in lower pH soils (4.0-5.3). In addition, Nitrososphaerales clade $\mathrm{C} 10$ was abundantly detected in many lower $\mathrm{pH}$ soils from previous studies, which was not observed in our soils. Interestingly, based on DNA-based stable isotope probing studies, the most actively growing Nitrososphaerales clades in these low $\mathrm{pH}$ agricultural soils were restricted to clades of $\mathrm{C} 1 / \mathrm{C} 2, \mathrm{C} 3$ and C11 (Table 2) [9, 19, 40]. This indicated the lifestyles and metabolic traits of different AOA clades might be distinct. While millions years of evolution separate these AOA clades and associated metabolic traits $[5,35]$, AOA adaptation to such acidic conditions was likely facilitated by acquisition of V-type ATPases via horizontal transfer [41] or other traits linked to $\mathrm{pH}$ homeostasis [42].

\section{Influence of Different Fertilisation Histories on AOA Composition and Abundance}

We also hypothesized that proportion of Nitrososphaerales AOA would be greater in the low $\mathrm{pH}$ agricultural soils receiving higher nutrient supplies of NPK or manure amendment. However, this study did not observe significant difference of Nitrososphaerales proportions between soils receiving all major nutrient elements (NPK, 1/2NPK and $1 / 2 \mathrm{NPK}+\mathrm{OM}$ ) and those with one nutrient element unamended (NP, NK, PK). Different nutrient amendments appeared to have no direct impact on the AOA community compositions, but the consequent change in soil $\mathrm{pH}$ condition might be one of the key drivers, according to correlation test on several environmental variables (Fig. 2). Indeed, $\mathrm{pH}$ could roughly classify the soils into two main groups, one with more acidic $\mathrm{pH}$ range (NK, NP, NPK and $1 / 2 \mathrm{NPK}$,
$\mathrm{pH} \leq 5.2)$ having closer AOA community structure compared to the higher $\mathrm{pH}$ soil group ( $\mathrm{PK}$ and $1 / 2 \mathrm{NPK}+\mathrm{OM}$, pH 5.7-6.3) (Fig. 2). These two groups of soils were also dominated by distinct AOA clades as discussed above and had different AOA diversity indices (Fig. S2). Some nutrient factors, e.g. soil $\mathrm{NH}_{4}{ }^{+}$concentration, also showed consistency with AOA composition based on multivariate analyses (Fig. 2). However, their role in shaping AOA community assembly is uncertain, as most of these factors are fluctuating with agricultural management.

Although the multiple nutrient supplies might not determine the composition of AOA in our soils, the amendment or lack of certain nutrient element might affect the ammonia oxidiser activity. For instance, there was no significant difference observed in soil pH (Table 1) and ammonia oxidiser abundance (Fig. 3a) between NP, NPK and $1 / 2$ NPK treatments, but the nitrification rate was the lowest in NP soil without K supply history, suggesting that increased $\mathrm{K}$ supply could be a factor enhancing the ammonia oxidiser activity. Additionally, the only soil without $\mathrm{P}$ fertiliser application (NK) had both the lowest ammonia oxidiser abundance and nitrification rate. Since NK soil also had the lowest $\mathrm{pH}$, we cannot disentangle the influence of $\mathrm{P}$ element from the $\mathrm{pH}$ change. However, an enhanced microbial $\mathrm{N}$ cycling, including nitrification process, was previously observed following $\mathrm{P}$ addition in agricultural soils [43, 44]. Lastly, organic manure fertilisation history also had significant effect on the AOA composition (Table $\mathrm{S} 1$ ) and the soil receiving such fertilisation had the highest nitrification rate in our study (Fig. 3). Because this soil also had the highest $\mathrm{pH}$, it is difficult to distinguish which factor is more determinant of such 
observation. Nevertheless, a previous study observed that organic mature fertilisation induced an increased nitrification rate without a change in soil $\mathrm{pH}$ [45], implying that other environmental elements important for ammonia oxidiser activity might have been introduced in soils following mature fertilisation regime. Indeed, the soil fertilised with manure accumulated the highest SOM content among all soils used in this study (Table 1) and such SOM concentration might favour high AOA growth, as AOA grow well under supply of ammonia originating from organic $\mathrm{N}$ mineralisation $[22,46]$.

\section{Conclusion}

The present study revealed a high abundance of Nitrososphaerales AOA in typical Chinese acidic red soils following different agricultural managements. Different longterm fertilisation regimes applied to the soils altered the relative abundance of several major Nitrososphaerales clades in soils, i.e. C1, C2 and C6, likely through perturbation of soil $\mathrm{pH}$. Our results suggested that the high abundance and associated physiological adaptation to these low soil $\mathrm{pH}$ conditions were not restricted to previously recognized AOA clades, i.e. Ca. Nitrosotaleaceae $\mathrm{C} 14$ and Nitrososphaerales $\mathrm{C} 11$. The major Nitrososphaerales clades identified in our soils are potentially responsible for the in situ ammonia oxidation process, but assessment of their activity and relative contribution requires further investigation using high sensitivity techniques, such as DNA-stable isotope probing or RNA-based tools.

Supplementary Information The online version contains supplementary material available at https://doi.org/10.1007/s00248-021-01763-2.

Acknowledgements We thank Prof Yuanqiu He (now deceased) at the State Key Laboratory of Soil and Sustainable Agriculture, Institute of Soil Science, Chinese Academy of Sciences for his contribution to this study. In addition, we thank the staff of the Analysis Center at the Institute of Soil Science for technical support, including Ms Rong Huang and Mr Zuohao Ma for 454-pyrosequencing, Mr Ruhai Wang for the ammonia and nitrate and nitrite content assays, Mr Guoxing Lu for the SOM assay. We also thank Dr Jian Cui and Dr Xiaoli Liu for assistance in soil sampling in the fields.

Funding This work was supported by the National Natural Science Foundation of China (41530857, 91751204 and 41977056). JZ was funded by a Natural Environment Research Council grant (NE/ K016342/1) and CGR was supported by a Royal Society University Research Fellowship (URF150571).

Data Availability The pyrosequencing reads of archaeal amoA genes have been deposited at European Nucleotide Archive (ENA) with accession number PRJEB40021.

\section{Declarations}

Competing Interests The authors declare no competing interests.

Open Access This article is licensed under a Creative Commons Attribution 4.0 International License, which permits use, sharing, adaptation, distribution and reproduction in any medium or format, as long as you give appropriate credit to the original author(s) and the source, provide a link to the Creative Commons licence, and indicate if changes were made. The images or other third party material in this article are included in the article's Creative Commons licence, unless indicated otherwise in a credit line to the material. If material is not included in the article's Creative Commons licence and your intended use is not permitted by statutory regulation or exceeds the permitted use, you will need to obtain permission directly from the copyright holder. To view a copy of this licence, visit http://creativecommons.org/licenses/by/4.0/.

\section{References}

1. von Uexküll HR, Mutert E (1995) Global extent, development and economic impact of acid soils. Plant Soil 171:1-15

2. Tian D, Niu S (2015) A global analysis of soil acidification caused by nitrogen addition. Environ Res Lett 10. https://doi.org/10.1088/ 1748-9326/10/2/024019

3. Meng C, Tian D, Zeng H, Li Z, Yi C, Niu S (2019) Global soil acidification impacts on belowground processes. Environ Res Lett 14. https://doi.org/10.1088/1748-9326/ab239c

4. Booth MS, Stark JM, Rastetter E (2005) Controls on nitrogen cycling in terrestrial ecosystems: a synthetic analysis of literature data. Ecol Monogr 75:139-157

5. Gubry-Rangin C, Hai B, Quince C, Engel M, Thomson BC, James P, Schloter M, Griffiths RI, Prosser JI, Nicol GW (2011) Niche specialization of terrestrial archaeal ammonia oxidizers. Proc Natl Acad Sci U S A 108:21206-21211. https://doi.org/10.1073/pnas. 1109000108

6. Nicol GW, Leininger S, Schleper C, Prosser JI (2008) The influence of soil $\mathrm{pH}$ on the diversity, abundance and transcriptional activity of ammonia oxidizing archaea and bacteria. Environ Microbiol 10:2966-2978. https://doi.org/10.1111/j.1462-2920. 2008.01701.x

7. Gubry-Rangin C, Nicol GW, Prosser JI (2010) Archaea rather than bacteria control nitrification in two agricultural acidic soils. FEMS Microbiol Ecol 74:566-574. https://doi.org/10.1111/j. 1574-6941.2010.00971.x

8. Lu L, Han W, Zhang J, Wu Y, Wang B, Lin X, Zhu J, Cai Z, Jia Z (2012) Nitrification of archaeal ammonia oxidizers in acid soils is supported by hydrolysis of urea. ISME J 6:1978-1984. https:// doi.org/10.1038/ismej.2012.45

9. Zhang L-M, Hu H-W, Shen J-P, He J-Z (2012) Ammonia-oxidizing archaea have more important role than ammonia-oxidizing bacteria in ammonia oxidation of strongly acidic soils. ISME J 6:1032-1045. https://doi.org/10.1038/ismej.2011.168

10. Xu X, Xia Z, Liu Y, Liu E, Muller K, Wang H, Luo J, Wu X, Beiyuan J, Fang Z, Xu J, Di H, Li Y (2021) Interactions between methanotrophs and ammonia oxidizers modulate the response of in situ methane emissions to simulated climate change and its legacy in an acidic soil. Sci Total Environ 752:142225. https:// doi.org/10.1016/j.scitotenv.2020.142225

11. Zhang LM, Offre PR, He JZ, Verhamme DT, Nicol GW, Prosser JI (2010) Autotrophic ammonia oxidation by soil thaumarchaea. Proc Natl Acad Sci U S A 107:17240-17245. https://doi.org/10. 1073/pnas.1004947107 
12. Pratscher J, Dumont MG, Conrad R (2011) Ammonia oxidation coupled to $\mathrm{CO} 2$ fixation by archaea and bacteria in an agricultural soil. Proc Natl Acad Sci U S A 108:4170-4175. https://doi.org/ 10.1073/pnas.1010981108

13. Zhao J, Meng Y, Drewer J, Skiba UM, Prosser JI, Gubry-Rangin C (2020) Differential ecosystem function stability of ammoniaoxidizing archaea and bacteria following short-term environmental perturbation. mSystems 5. https://doi.org/10.1128/mSystems. 00309-20

14. Aigle A, Gubry-Rangin C, Thion C, Estera-Molina KY, Richmond H, Pett-Ridge J, Firestone MK, Nicol GW, Prosser JI (2020) Experimental testing of hypotheses for temperature- and $\mathrm{pH}$-based niche specialisation of ammonia oxidising archaea and bacteria. Environ Microbiol. https://doi.org/10.1111/1462-2920.15192

15. Aigle A, Prosser JI, Gubry-Rangin C (2019) The application of high-throughput sequencing technology to analysis of amoA phylogeny and environmental niche specialisation of terrestrial bacterial ammonia-oxidisers. Environ Microbiome 14.https:// doi.org/10.1186/s40793-019-0342-6

16. Sheridan PO, Raguideau S, Quince C, Holden J, Zhang L, Thames C, Williams TA, Gubry-Rangin C (2020) Gene duplication drives genome expansion in a major lineage of Thaumarchaeota. Nat Commun 11:5494. https://doi.org/10.1038/ s41467-020-19132-x

17. Alves RJE, Minh BQ, Urich T, von Haeseler A, Schleper C (2018) Unifying the global phylogeny and environmental distribution of ammonia-oxidising archaea based on amoA genes. Nat Commun 9:1517. https://doi.org/10.1038/s41467-018-03861-1

18. Gubry-Rangin C, Williams W, Prosser JI (2018) Approaches to understanding the ecology and evolution of understudied terrestrial archaeal ammonia-oxidisers. Emerg Top Life Sci 2:619-628. https://doi.org/10.1042/etls20180018

19. Wang B, Zheng Y, Huang R, Zhou X, Wang D, He Y, Jia Z (2014) Active ammonia oxidizers in an acidic soil are phylogenetically closely related to neutrophilic archaeon. Appl Environ Microbiol 80:1684-1691. https://doi.org/10.1128/AEM.03633-13

20. Pester M, Rattei T, Flechl S, Gröngröft A, Richter A, Overmann J, Reinhold-Hurek B, Loy A, Wagner M (2012) amoA-based consensus phylogeny of ammonia-oxidizing archaea and deep sequencing of amoA genes from soils of four different geographic regions. Environ Microbiol 14:525-539. https://doi.org/10.1111/j. 1462-2920.2011.02666.X

21. Zhao J, Bello MO, Meng Y, Prosser JI, Gubry-Rangin C (2020) Selective inhibition of ammonia oxidising archaea by simvastatin stimulates growth of ammonia oxidising bacteria. Soil Biol Biochem. 141https://doi.org/10.1016/j.soilbio.2019.107673

22. Hink L, Gubry-Rangin C, Nicol GW, Prosser JI (2018) The consequences of niche and physiological differentiation of archaeal and bacterial ammonia oxidisers for nitrous oxide emissions. ISME J 12:1084-1093. https://doi.org/10.1038/s41396-017-0025-5

23. Xu X, Liu Y, Singh BP, Yang Q, Zhang Q, Wang H, Xia Z, Di H, Singh BK, Xu J, Li Y (2020) NosZ clade II rather than clade I determine in situ $\mathrm{N} 2 \mathrm{O}$ emissions with different fertilizer types under simulated climate change and its legacy. Soil Biol Biochem 150 https://doi.org/10.1016/j.soilbio.2020.107974

24. He JZ, Shen JP, Zhang LM, Zhu YG, Zheng YM, Xu MG, Di H (2007) Quantitative analyses of the abundance and composition of ammonia-oxidizing bacteria and ammonia-oxidizing archaea of a Chinese upland red soil under long-term fertilization practices. Environ Microbiol 9:2364-2374. https://doi.org/10.1111/j.14622920.2007.01358.x

25. Tourna M, Freitag TE, Nicol GW, Prosser JI (2008) Growth, activity and temperature responses of ammonia-oxidizing archaea and bacteria in soil microcosms. Environ Microbiol 10:1357-1364. https://doi.org/10.1111/j.1462-2920.2007.01563.x
26. Schloss PD, Westcott SL, Ryabin T, Hall JR, Hartmann M, Hollister EB, Lesniewski RA, Oakley BB, Parks DH, Robinson CJ, Sahl JW, Stres B, Thallinger GG, Van Horn DJ, Weber CF (2009) Introducing mothur: open-source, platform-independent, community-supported software for describing and comparing microbial communities. Appl Environ Microbiol 75:7537-7541. https://doi. org/10.1128/AEM.01541-09

27. Francis CA, Roberts KJ, Beman JM, Santoro AE, Oakley BB (2005) Ubiquity and diversity of ammonia-oxidizing archaea in water columns and sediments of the ocean. Proc Natl Acad Sci USA 102:14683-14688

28. Rotthauwe J-h, Witzel K-p, Liesack W (1997) The ammonia monooxygenase structural gene amoA as a functional marker: Molecular fine-scale analysis of natural ammonia-oxidizing populations. Appl Environ Microbiol 63:4704-4712

29. Zhang J, Zhu T, Cai Z, Müller C (2011) Nitrogen cycling in forest soils across climate gradients in Eastern China. Plant Soil 342:419-432. https://doi.org/10.1007/s11104-010-0706-6

30. Norton JM, Alzerreca JJ, Suwa Y, Klotz MG (2002) Diversity of ammonia monooxygenase operon in autotrophic ammoniaoxidizing bacteria. Arch Microbiol 177:139-149. https://doi.org/ 10.1007/s00203-001-0369-z

31. Stieglmeier M, Mooshammer M, Kitzler B, Wanek W, Zechmeister-Boltenstern S, Richter A, Schleper C (2014) Aerobic nitrous oxide production through $\mathrm{N}$-nitrosating hybrid formation in ammonia-oxidizing archaea. ISME J 8:1135-1146. https://doi. org/10.1038/ismej.2013.220

32. Lehtovirta-Morley LE, Stoecker K, Vilcinskas A, Prosser JI, Nicol GW (2011) Cultivation of an obligate acidophilic ammonia oxidizer from a nitrifying acid soil. Proc Natl Acad Sci 108:1589215897. https://doi.org/10.1073/pnas. 1107196108

33. Prosser JI, Nicol GW (2012) Archaeal and bacterial ammoniaoxidisers in soil: the quest for niche specialisation and differentiation. Trends Microbiol 20:523-531. https://doi.org/10.1016/j.tim. 2012.08.001

34. Philip D (2003) VEGAN, a package of R functions for community ecology. J Veg Sci 14:927-930

35. Gubry-Rangin C, Novotnik B, Mandič-Mulec I, Nicol GW, Prosser JI (2017) Temperature responses of soil ammonia-oxidising archaea depend on pH. Soil Biol Biochem 106:61-68. https:// doi.org/10.1016/j.soilbio.2016.12.007

36. Liao J, Cao X, Zhao L, Wang J, Gao Z, Wang MC, Huang Y (2016) The importance of neutral and niche processes for bacterial community assembly differs between habitat generalists and specialists. FEMS Microbiol Ecol 92 https://doi.org/10.1093/femsec/ fiw 174

37. Sriswasdi S, Yang CC, Iwasaki W (2017) Generalist species drive microbial dispersion and evolution. Nat Commun 8:1162. https:// doi.org/10.1038/s41467-017-01265-1

38. Jones SE, Lennon JT (2010) Dormancy contributes to the maintenance of microbial diversity. Proc Natl Acad Sci U S A 107:58815886. https://doi.org/10.1073/pnas.0912765107

39. Allison SD, Martiny JBH (2008) Resistance, resilience, and redundancy in microbial communities. Proc Natl Acad Sci 105:11512-11519

40. Li Y, Xi R, Wang W, Yao H (2019) The relative contribution of nitrifiers to autotrophic nitrification across a $\mathrm{pH}$-gradient in a vegetable cropped soil. J Soils Sediments 19:1416-1426. https:// doi.org/10.1007/s11368-018-2109-x

41. Wang B, Qin W, Ren Y, Zhou X, Jung MY, Han P, Eloe-Fadrosh EA, Li M, Zheng Y, Lu L, Yan X, Ji J, Liu Y, Liu L, Heiner C, Hall R, Martens-Habbena W, Herbold CW, Rhee SK, Bartlett DH, Huang L, Ingalls AE, Wagner M, Stahl DA, Jia Z (2019) Expansion of Thaumarchaeota habitat range is correlated with horizontal transfer of ATPase operons. ISME J 13:3067-3079. https://doi. org/10.1038/s41396-019-0493-x 
42. Herbold CW, Lehtovirta-Morley LE, Jung MY, Jehmlich N, Hausmann B, Han P, Loy A, Pester M, Sayavedra-Soto LA, Rhee SK, Prosser JI, Nicol GW, Wagner M, Gubry-Rangin C (2017) Ammonia-oxidising archaea living at low $\mathrm{pH}$ : insights from comparative genomics. Environ Microbiol 19:4939-4952. https://doi.org/10. 1111/1462-2920.13971

43. Cheng Y, Wang J, Sun N, Xu M, Zhang J, Cai Z, Wang S (2018) Phosphorus addition enhances gross microbial $\mathrm{N}$ cycling in phosphorus-poor soils: a $15 \mathrm{~N}$ study from two long-term fertilization experiments. Biol Fertil Soils 54:783-789. https://doi.org/10. 1007/s00374-018-1294-5

44. Wei X, Hu Y, Peng P, Zhu Z, Atere CT, O'Donnell AG, Wu $\mathrm{J}, \mathrm{Ge} \mathrm{T}$ (2017) Effect of P stoichiometry on the abundance of nitrogen-cycle genes in phosphorus-limited paddy soil. Biol Fertil Soils 53:767-776. https://doi.org/10.1007/s00374-017-1221-1

45. Ouyang Y, Reeve JR, Norton JM (2018) Soil enzyme activities and abundance of microbial functional genes involved in nitrogen transformations in an organic farming system. Biol Fertil Soils 54:437-450. https://doi.org/10.1007/s00374-018-1272-y

46. Levicnik-Hofferle S, Nicol GW, Ausec L, Mandic-Mulec I, Prosser JI (2012) Stimulation of thaumarchaeal ammonia oxidation by ammonia derived from organic nitrogen but not added inorganic nitrogen. FEMS Microbiol Ecol 80:114-123. https:// doi.org/10.1111/j.1574-6941.2011.01275.x 